\title{
FAKTOR PENDUKUNG DAN PENGHAMBAT PERAN BADAN \\ PERMUSYAWARATAN DESA TAWENGAN DALAM \\ PROSES PENETAPAN PERATURAN DESA
}

\author{
Sri Nurhayati \\ E-mail : snurhayati0803@gmail.com \\ Mahasiswa Magister Kebijakan Publik Universitas Sebelas Maret \\ Agus Riwanto \\ E-mail: agusriewanto@yahoo.com \\ Isharyanto \\ E-mail: Isharyantoisharyanto8@ gmail.com
}

\section{Dosen Fakultas Hukum Universitas Sebelas Maret Surakarta}

\begin{abstract}
The Village Consultative Board (BPD) is a representative consisting of village leaders who function to protect the customs, make regulations in the village, accommodate and channel the aspirations of the community and conduct supervision on the implementation of village government. This research is intended to know about the supporting and inhibiting factors of the role of Village Consultative Board in the process of drafting and stipulating the Village Regulation, Case Study in Tawengan Village. The writing of this law employs empirical juridical methods. From the existing data, the Village Regulations are made, more Village Regulations relating to APBDes and LPJ Village Head. Implementation and effectiveness describes institutions that are building and developing Perdes, which Kadesh and BPD have not been able to formulate the Peres Retakdes (Raperdes) that can be received from the side of the design of legislation drafting (law drafting). In fact, most do not yet know firsthand what the Village Rule and its forms are.
\end{abstract}

Keywords: Facto; Role Village Consultative Board (BPD); Village regulations.

\begin{abstract}
Abstrak
Badan Permusyawaratan Desa (BPD) merupakan perwakilan yang terdiri atas pemuka-pemuka masyarakat Desa yang berfungsi mengayomi adat istiadat, membuat peraturan yang ada di Desa, menampung dan menyalurkan aspirasi masyarakat serta melakukan pengawasan terhadap penyelenggaraan pemerintah Desa. Penelitian ini bertujuan untuk mengetahui tentang faktor pendukung dan penghambat peran Badan Permusyawaratan Desa dalam proses penyusunan dan penetapan Peraturan Desa, Studi Kasus di Desa Tawengan. Penulisan hukum ini menggunakan metode yuridis empiris. Dari data yang ada mayoritas Peraturan Desa yang dibuat, lebih banyak Peraturan Desa yang berkaitan dengan APBDes dan LPJ Kepala desa. Implementasi dan efektifitas menjelaskan bahwa lembagalembaga Desa yang berwenang menjalankan dan membentuk Perdes, yakni
\end{abstract}


Kades dan BPD belum mampu merumuskan Rancangan Perdes (Raperdes) yang dapat diterima dari sisi teknik perancangan peraturan perundang-undangan (legal drafting). Bahkan, sebagian besar belum tahu secara persis apa itu Peraturan Desa dan bentuk-bentuknya.

Kata kunci : Faktor; Peran BPD; Perdes.

\section{A. Pendahuluan}

Awal pemerintahan Desa di Indonesai dimulai sebelum kolonial belanda masuk ke indonesia, sebagaimana diilustrasikan oleh Cornellis Van Vollen Hoven bahwa sebelum masa penjajah belanda ke nusantara sudah terdapat sistem ketatanegaraan dalam bentuk kesatuan perkampungan, (Nasroen, 1955: 41). Pada awal nya Desa merupakan organisasi komunital lokal yang mempunyai batasan wilayah, dihuni oleh sejumlah penduduk dan mempunyai adat istiadat untuk mengurus urusan rumah tangganya sendiri. Dengan sebutan lain self governing, sebutan desa sebagai kesatuan masyarakat hukum di kenal pada masa kolonial Belanda, (Sutoro Eko, 2005: 444). Desa merupakan suatu kesatuan hukum yang terdapat suatu masyarakat berkuasa mengadakan pemerintah dan aturan-aturan yang harus di patuhi oleh masyarakat setempat.

Undang-Undang Nomor 6 Tahun 2014 tentang Pemerintahan Desa sebagai mana penjabaran dari Undang-Undang Nomor 23 Tahun 2014 tentang Pemerintahan Daerah, Badan Permusyawaratan Desa (BPD) dalam Pasal 55 menjelaskan bahwa Badan Perwakilan Desa atau yang disebut dengan nama lain berfungsi membuat Peraturan Desa, menampung dan menyalurkan aspirasi masyarakat, serta melakukan pengawasan terhadap penyelenggara Pemerintahan Desa.

Peraturan Desa/peraturan yang setingkat merupakan peraturan perundangundangan yang dibuat oleh Badan Permusyawarahan Desa bersama dengan Kepala Desa. Badan permusyawaratan ialah lembaga yang melakukan fungsi pemerintahan yang anggotanya merupakan wakil dari penduduk desa berdasarkan keterwakilan wilayah dan ditetapkan secara demokratis.kewajiban badan permusyawaratan desa adalah menampung, menyerap, menghimpun dan menindaklanjuti aspirasi masyarakat desa, badan permusyawaratan desa 
merupakan badan permusyawaratan ditingkat desa yang turut aktif membahas menyepakati berbagai kebijakan atau peraturan dalam penyelenggaraan pemerintah desa. selain menyepakati peraturan desa, badan permusyawaratan desa berhak mengawasi dan meminta keterangan tentang penyelenggaraan Pemerintahan Desa kepada Pemerintah Desa, serta mendapatkan biaya biaya operasional pelaksanaan tugas dan fungsi nya dari anggaran pendapatan dan belanja Desa.

HAW. Widjaja, 2003: 3 Menjelaskan Peraturan Desa merupakan peraturan yang ditetapkan oleh Kepala Desa setelah dimusyawarahkan dan telah mendapatkan persetujuan Badan Perwakilan Desa.Kedua definisi peraturan desa ini masih menekankan pada lembaga yang berwenang membuat peraturan desa, belum menyentuh pada kedudukan, materi muatan dan fungsi peraturan desa itu sendiri sebagai bagian dari peraturan perundang-undangan. Justru itu, sebagai pegangan, Peraturan Desa dapat didefinisikan sebagai peraturan perundangundangan yang kedudukannya di bawah Peraturan Daerah Kabupaten/Kota yang dibuat oleh Badan Perwakilan/Permusyawaratan Desa bersama Kepala Desa untuk mengatur semua kewenangan desa beserta tugas pembantuan (medebewind). Dari definisi ini diketahui bahwa kedudukan Peraturan Desa berada di bawah Peraturan Daerah Kabupaten/Kota.

Implementasi dan efektifitas menjelaskan bahwa lembaga-lembaga desa yang berwenang menjalankan dan membentuk Perdes, yakni Kades dan BPD belum mampu merumuskan Rancangan Perdes (Raperdes) yang dapat diterima dari sisi teknik perancangan peraturan perundang-undangan (legal drafting).Bahkan, sebagian besar belum tahu secara persis apa itu Peraturan Desa dan bentuk-bentuknya.

Kondisi tersebut kemudian menjadi kendala utama jalannya roda pemerintahan desa. Padahal, hakikat hukum dari "otonomi desa" didalamnya melekat wewenang untuk "mengatur" kepentingan masyarakat desa setempat. Kata "mengatur" ini dapat ditafsirkan sebagai kekuasaan atau kewenangan membentuk Perdes. 
Berdasarkan Uraian diatas maka dalam artikel ini hendak membahas factor pendukung dan penghanbat peran BPD (Badan Permusyawaratan Desa ) Desa Tawengan dalam proses penetapan Peraturan Desa.

\section{B. MetodePenelitian}

Jenis yang dipakai dalam penelitian ini adalah penelitian yuridis empiris, yang mana untuk mendukung perkembangan ilmu hukum tidak cukup hanya dilakukan dengan melakukan studi mengenai sistem norma saja.

Ahli hukum harus mampu memberikan penjelasan mengenai proses penegakan hukum yang sering kali berjalan lambat, atau mengapa masyarakat tidak menaati hukum serta menjelaskan hubungan antara banyaknya pengangguran dengan tingkat kriminalitas di masyarakat.hal ini memang tidak mampu dijelaskan secara normatif saja, ahli hukum sebaiknya juga memahami kondisi dan situasi sosial kemayarakatan dimana hukum itu di tempatkan. Maka dari itu, penstudi dan pratisi hukum juga perlu melakukan penelitian hukum secara empiris, (Mukti Fajar, 2017: 43).

Satjipto raharjo mengatakan bahwa " untuk mampu memahami hukum lalu lintas tidak bisa hanya membaca peraturan perundang-undangan tentang lalu lintas saja, akan tetapi juga harus secara langsung turun dan mengamati apa yang terjadi di jalan raya", (Sajipto Raharjo, 2006: 96).

Berdasarkan uraian di atas maka dalam Artikel ini hendak membahas:

\section{Hasil Penelitian dan Pembahasan}

Secara Teorotis, pembuatan peraturan perundang-undangan belum bisa dilakukan tanpa ada struktur pembuatan hukum sebagai wadahnya. Struktur pembuatan hukum didasarkan pada pembagian kekuasaan antara legislatif, yudikatif dan eksekutif.Struktur ini tidak berdiri sendiri-sendiri, namun lebih merupakan bagian dari penataan ketatanegaraan yang lebih luas. Dengan adanya pemisahan aktifitas ketatanegaraan menjadi tiga tersebut, maka pembuatan hukum akan berjalan melalui proses yang 
eksklusif. Pedoman Teknis Pembuatan Peraturan Desa di atur dalam Peraturan Menteri Dalam Negeri Nomor 111 Tahun 2014.

Peraturan Desa adalah Peraturan yang meliputi Peraturan Desa, Peraturan Bersama Kepala Desa dan Peraturan Kepala Desa, (Mohamad Syaiffulah, 2005). Peraturan Desa adalah Peraturan Perundang-undangan yang ditetapkan oleh Kepala Desa setelah dibahas dan disepakati bersama Badan Permusyawaratan Desa (BPD). Peraturan Desa berisi materi pelaksanaan kewenangan desa dan penjabaran lebih lanjut dari Peraturan Perundang-undangan yang lebih tinggi, Peraturan Desa dibuat dalam rangka penyelenggaraan pemerintahan Desa, dengan demikian Peraturan Desa merupakan penjabaran dari Peraturan Perundang-undangan yang lebih tinggi dan tidak boleh bertentangan dengan kepentingan umum, yang dimaksud Bertentangan dengan kepentingan umum adalah kebijakan yang menyebabkan terganggunya kerukunan antar warga masyarakat, terganggunya akses terhadap pelayanan publik, terganggunya ketentraman dan ketertiban umum, terganggunya kegiatan ekonomi untuk meningkatkan kesejahteraan masyarakat dan/atau diskriminasi terhadap suku, agama dan kepercayaan, ras, antar golongan, dan gender.

Peran Badan Permusyawaratan Desa di Desa Tawengan Kecamatan Sambi Kabupaten Boyolali dalam menghasilkan Peraturan Desa dapat dirasakan masih sangat kurang berperan. Karena sampai saat ini hasil Peraturan Desa belum ada yang berasal dari usulan atau inisiatif dari Badan Permusyawaratan Desa akan tetapi mengikuti dengan Peraturan Desa yang disiapkan oleh Kepala Desa, sedang Kepala Desa hanya membuat Peraturan Desa sesuai dengan petunjuk dari kecamatan atau dari Kabupaten saja. Keseluruhan dari Peraturan Desa tersebut yaitu 7 Peraturan Desa pihak Desa mendapatkan salinan atau contohnya dari pihak kecamatan. Baik dan tidaknya peran Badan Permusyawaratan Desa dalam hal memberikan inisiatif atas Rancangan Peraturan Desa, tidak lepas dari peran dari masing-masing anggota Badan Permusyawaratan Desa. Peran anggota Badan Permusyawaratan Desa di Desa Tawengan 
dalam membuat Peraturan Desa, yang aktif memberikan masukan hanya beberapa orang saja, Peran aktif tersebut lebih kepada perannya dalam sidang, bukan terkait dengan memberikan masukan. Dalam hal kedatangan sewaktu ada Undangan untuk Penetapan Peraturan Desa semua Badan Permusyawaratan Desa Tawengan aktif datang. Peran anggota Badan Permusyawaratan Desa di Desa Tawengan secara umum belum sesuai dengan peraturan Perundang-undangan. Dalam Peraturan Menteri Dalam Negeri Republik Indonesia Nomor 111 Tahun 2014 Bab III, Bagian Kesatu , Perencanaan Peraturan Desa Pasal 5 berbunyi: (1) Perencanaan penyusunan rancangan Peraturan Desa ditetapkan oleh Kepala Desa dan Badan Permusyawaratan Desa dalam rencana kerja Pemerintah Desa; (2) Lembaga kemasyarakatan, lembaga adat dan lembaga Desa lainnya di Desa dapat memberikan masukan kepada Pemerintah Desa dan atau Badan Permusyawaratan Desa untuk rencana penyusunan Rancangan Peraturan Desa dan Peraturan Daerah Kabupaten Boyolali Nomor 10 Tahun 2015 tentang Pedoman Penyusunan Organisasi dan Tata Kerja Pemerintahan Desa Pasal 17 ayat (3) huruf a, b dan c.

Langkah-langkah dalam penyusunan Peraturan Desa di Desa Tawengan adalah:

a. Kepala Desa mengundang Badan Permusyawaratan Desa untuk membahas dan menyepakati Rancangan Peraturan Desa.

b. Dalam hal terdapat rancangan Peraturan Desa prakarsa Pemerintah Desa dan usulan Badan Permusyawaratan Desa mengenai hal yang sama untuk dibahas dalam waktu pembahasan yang sama, maka didahulukan rancangan Peraturan Desa usulan Badan Permusyawaratan Desa sedangkan Rancangan Peraturan Desa usulan Kepala Desa digunakan sebagai bahan untuk dipersandingkan. Akan tetapi sampai saat ini belum ada Peraturan Desa yang jadi atas usul Badan Permusyawaratan Desa.

c. Rancangan Peraturan Desa yang belum dibahas dapat ditarik kembali oleh pengusul. 
d. Rancangan Peraturan Desa yang telah dibahas tidak dapat ditarik kembali kecuali atas kesepakatan bersama antara Pemerintah Desa dan Badan Permusyawaratan Desa

e. Rancangan Peraturan Desa yang telah disepakati bersama disampaikan oleh pimpinan Badan Permusyawaratan Desa kepada Kepala Desa untuk ditetapkan menjadi peraturan Desa paling lambat 7 (tujuh) hari terhitung sejak tanggal kesepakatan.

f. Rancangan Peraturan Desa wajib ditetapkan oleh Kepala Desa dengan membubuhkan tanda tangan paling lambat 15 (lima belas) hari terhitung sejak diterimanya rancangan Peraturan Desa dari pimpinan Badan Permusyawaratan Desa

Salah satu penyebab ketidakefektifan pelaksanaan tugas dan fungsi dari lembaga ini khususnya pelaksanaan fungsi legislasi adalah karena minimnya pemahaman serta keterampilan dan kemampuan anggota BPD Desa Tawengan terhadap pelaksanaan fungsi legislasi tersebut.Kondisi ini juga sangat dipengaruhi oleh kurang tanggapnya aparat Kabupaten khususnya Dinas Pemberdyaan masyarakat Desa dan Lembaga Desa selaku pihak yang bertanggung jawab terhadap pembinaan kelembagaan.

Berdasarkan dari hasil wawancara dengan Ketua Badan Permusyawaratan Desa dan Kepala Desa di Desa Tawengan Kecamatan Sambi Kabupaten Boyolali, maka ketua BPD menyatakan Bahwa "ada beberapa faktor yang mempengaruhi pelaksanaan peran Badan Permusyawaratan Desa dalam proses penyusunan dan penetapan Peraturan Desa, jika dicermati telah terdapat berbagai kebiasaaan di Desa Tawengan yang sudah cukup lama terjadi tetapi belum diwujudkan dalam bentuk peraturan tertulis, hal ini mengindikasikan adanya beberapa faktor atau kendala dalam proses pembuatan Perdes terutama kendala formal yaitu kondisi di Desa yang lebih mengedepankan informal."

Dari data yang ada mayoritas Peraturan Desa yang dibuat, lebih banyak Peraturan Desa yang berkaitan dengan APBDes dan dan LPJ Kepala desa. Karena dari 7 Perdes ini maka 3 Perdes adalah tentang 
APBDes dan perubahannnya yaitu perda no. 1, 5, 7 dan 1 perdes yaitu nomor 6 tentang penghasilan tetap Kades dan perangkat, 1 Peraturan Desa tentang pembentukan panitia lelang tanah kas desa dan 1 Peraturan Desa yaitu nonor 6 tentang Rencana Kerja Pembangunan Desa Tawengan. Yang merupakan rencana keuangan tahunan Pemerintahan Desa yang dibahas dan disetujui bersama oleh Pemerintah Desa dan Badan Permusyawaratan Desa yang ditetapkan dengan Peraturan Desa. Setiap menjelang Tahun anggaran baru, Pemerintah Desa menyusun Anggaran Pendapatan dan Belanja Desa (APBDES) dengan Peraturan Desa dengan pedoman yang ditetapkan dengan Peraturan Bupati Boyolali. Anggaran Pendapatan dan Belanja Desa tersebut terdiri atas bagian Pendapatan Desa, Belanja Desa dan Pembiayaan dimana pelaksanaan Belanja Desa dan Pembiayaan berdasarkan pada prinsip Hemat, terarah dan terkendali sesuai dengan Rencana Anggaran Pemerintah Desa, Jadi Peraturan Desa yang di buat Pemerintah Desa Tawengan sesuai Peraturan Menteri Dalam Negeri Nomor 111 Tahun 2014, Bagian Kedua Paragraf 1, Penyusunan Peraturan Desa oleh Kepala Desa, Penyusunan Rancangan Peraturan Desa yang diprakarsai oleh Pemerintah Desa ( ayat 1 ).

Kendala Pelaksanaan Peran Badan Permusyawaratan Desa dalam proses Penetapan Peraturan desa antara lain :

a. Selama ini Anggota Badan Permusyawaratan Desa memiliki beragam profesi tersendiri sehingga memiliki kesibukan dalam bekerja sehingga untuk mengumpulkan dalam satu tempat dan satu waktu dirasakan cukup sulit karena kesibukan masing masing anggota.

b. Dalam proses Musyawarah Penetapan anggota Badan Permusyawaratan Desa cenderung untuk pasif dan kurang kritis dalam proses Penetapan Peraturan Desa sehingga proses Penetapan hanya menunggu inisiatif dari eksekutif

c. Insentif Anggota Badan Permusyawaratan Desa cukup sedikit yaitu hanya Rp. 100.000,- / bulan sehingga anggota Badan 
Permusyawaratan Desa lebih mengutamakan kegiatan non Badan Permusyawaratan Desa.

Badan Permusyawaratan Desa sebagai lembaga legislasi di Desa yang merumuskan dan menetapkan Peraturan Desa bersama-sama Pemerintah Desa. Peraturan Desa memuat ketentuan-ketentuan yang mengandung perintah, larangan atau keharusan untuk berbuat sesuatu dan atau tidak berbuat sesuatu yang ditujukan langsung kepada masyarakat, ketentuan yang memberikan beban kepada masyarakat dan segala sesuatu yang perlu diketahui oleh masyarakat Desa, karena menyangkut kepentingan masyarakat Desa. Lebih lanjut Peraturan Desa memuat juga materi tentang bentuk Peraturan Desa, muatan materi Peraturan Desa, tata cara penetapan Peraturan Desa terhadap kepentingan umum, peraturan daerah dan peraturan perundangan lainnya.

Tidak terlaksananya kinerja karena adanya saling harap antara Badan Permusyawaratan Desa dan Pemerintah Desa, meskipun Badan Permusyawaratan Desa dan Pemerintah Desa memahami betapa pentingnya Peraturan Desa, ini tidak bisa dilaksanakan. Selain itu hal ini dipengaruhi kurangnya kesadaran Badan Permusyawaratan Desa akan kinerja yang semestinya dan harus dilakukan dan tidak begitu memahami bagaimana kedudukan Badan Permusyawaratan Desa dalam Pemerintahan Desa. Badan Permusyawaratan Desa, Desa Tawengan juga kurang mengetahui bagaimana bentuknya Peraturan Desa, sehingga cenderung berharap dari Pemerintah Desa dan Badan Permusyawaratan Desa tinggal menyetujui saja setelah diperiksa. Tidak adanya Peraturan Desa selain dari Rencana Kerja Pembangunan Desa (RKPD), Laporan Pertanggungjawaban Pemerintah Desa (LPPD) di Desa Tawengan yang mana peraturan tersebut sudah terpandu dari kecamatan, maka secara langsung diketahui Badan Permusyawaratan Desa, karena selama ini Badan Permusyawaratan Desa hanya aktif di penetapan terhadap Peraturan Desa, padahal telah ada aturan tahapan yang jelas sebelum Peraturan Desa di Tetapkan. Rancangan Peraturan Desa disusun oleh Kepala Desa dan 
atau Badan Permusyawaratan Desa. Mekanisme musyawarah Badan Permusyawaratan Desa sudah di atur dalam Undang-undang Republik Indonesia Nomor 6 Tahun 2014 tentang Desa dalam Pasal 65, yang mana Badan Permusyawaratan Desa mengadakan musyawarah dan diyatakan sah apabila dihadiri oleh paling sedikit 2/3 (dua pertiga) dari jumlah anggota Badan Permusyawaratan Desa ( Undang-Undang Republik Indonesia Nomor 6 Tahun 2014 tentang Desa Pasal 65 ayat (1) huruf b).

\section{Simpulan}

Badan Permusyawaratan Desa berfungsi menetapkan Peraturan Desa bersama Kepala Desa, menampung dan menyalurkan aspirasi masyarakat dan melakukan pengawasan, disamping menjalankan fungsinya sebagai jembatan penghubung antara Kepala Desa dengan masyarakat Desa, juga dapat menjadi lembaga yang berperan sebagai lembaga representasi dari masyarakat. Pelaksanaan tugas dan fungsi dari Badan Permusyawaratan Desa pada dasarnya mengacu pada tugas dan fungsi dari lembaga yang telah diatur dalam Peraturan Per Undang-Undangan yaitu melaksanakan fungsi legislasi, menampung dan menyalurkan aspirasi masyarakat serta fungsi pengawasan, namun dalam pelaksanaannya pelaksanaan fungsi legislasi dari Badan Permusyawaratan Desa belum dilaksanakan secara efektif. Namun dalam hal ini Badan Permusyawaratan Desa di Desa Tawengan juga tidak menyalahi Peraturan dalam hal ini UndangUndang Nomor 6 Tahun 2014 tentang Desa dan Peraturan Pemerintah Nomor 111 Tahun 2014 tentang Pedoman Teknis Peraturan Desa Pasal 7 ayat (1) berbunyi Badan Permusyawaratan Desa dapat menyusun dan mengusulkan rancangan Peraturan Desa, ayat (2) Rancangan Peraturan Desa sebagaimana dimaksud pada ayat (1) kecuali untuk rancangan Peraturan Desa tentang rencana pembangunan jangka menengah Desa, Rancangan Peraturan Desa tentang rencana kerja Pemerintah Desa, rancangan Peraturan Desa tentang APB Desa dan rancangan Peraturan Desa tentang Laporan Pertanggungjawaban realisasi pelaksanaan APBDesa, karena pada kenyataanya Badan Permusyawaratan Desa Tawengan belum pernah mengajukan Rancangan Peraturan Desa. 
Salah satu faktor pendukung pelaksanaan Peran Badan Permusyawaratan Desa dalam proses Penyusunan dan Penetapan Peraturan Desa adalah masyarakat sebagai penentu keberhasilan dalam melaksanakan fungsinya, pelaksanaan proses pembuatan aturan Pemerintah Desa harus melibatkan masyarakat sebagai subyek pembangunan Desa dan penyebab ketidak efektifan pelaksanaan tugas dan fungsi dari lembaga ini khususnya pelaksanaan legislasi adalah karena minimnya pemahaman serta ketrampilan dan kemampuan anggota Badan Permusyawaratan Desa dalam Merancang dan Membuat sebuah Peraturan Desa, dalam hal ini Pemerintah belum menjalankan aturan yang di buat, dalam Peraturan Daerah Kabupaten Boyolali Nomor 10 Tahun 2015 tentang Pedoman Penyusunan Organisasi dan Tata Kerja Pemerintahan Desa Pasal 19 ayat (1) Pemerintah Daerah berwenang membina dan mengawasi penyelenggaraan Pemerintah Desa, Pasal 20 Pembinaan dan pengawasan yang dilakukan oleh Pemerintah Daerah sebagimana dimaksud dalam Pasal 19 ayat (1) meliputi: huruf i berbunyi menyelenggarakan pendidikan dan pelatihan bagi Pemerintah Desa, Badan Permusyawaratan Desa, Lembaga Kemasyarakatan , dan lembaga adat.

\section{E. Saran}

Peran anggota Badan Permusyawaratan Desa di Desa Tawengan masih pasif dalam pembentukan Peraturan Desa, dan ternyata hal tersebut dipengaruhi oleh faktor Pendidikan, Pekerjaan, dan Pengalaman menjabat, seharusnya di dalam melakukan pemilihan anggota Badan Permusyawaratan Desa memperhatikan faktor-faktor tersebut

Perlunya melakukan pembinaan, pendidikan dan pelatihan teknis kepada para anggota Badan Permusyawaratan Desa di Desa Tawengan. Perlu mengupayakan kaderisasi calon-calon anggota BPD di desa Tawengan yang dinilai kapabel dan sedapat mungkin mewakili seluruh elemen masyarakat dan tidak hanya sekedar mengandalkan faktor ketokohan semata

Pemahaman yang lebih mendalam terhadap dinas atau instansi Pemerintahan Daerah tentang sistem Pemerintahan Desa dan memberikan keleluasaan Kepada Desa untuk menentukan kebijakan yang akan diambil dalam 
sistem Pemerintahan Desa. Pengadaan sarana dan prasarana serta perumusan kebijakan guna meningkatkan jumlah kompensasi atau honor maupun anggaran khusus untuk melaksaakan fungsi yang diterima oleh BPD.

\section{F. Daftar Pustaka}

\section{Buku}

aka

Bambang T Soemantri. 2011. Pedoman Penyelenggaraan Pemerintah Desa. Jakarta: Focus Media.

Esmi Warassih. 2005. Pranata Hukum Sebuah Telaah Sosiologis. Semarang: PT Suryandaru Utama.

Ijiswara F. 2000. Pengantar Ilmu Politik. Bandung: Putra A Bardin.

Miriam Budiarjo. 2001. Dasar-Dasar Ilmu politik. Jakarta: PT Gramedia Pustaka.

Mukti fajar ND. Yulianto achmad,MH, 2017, Dualisme Penelitian Hukum Normatif Dan Empiris, Pustaka Pelajar, Yogyakarta.

Nasroen. 1955. Daerah Otonomi Tingkat Terbawah. Jakarta: Beringin Tranding Company.

Satjipto Raharjo, 2006, Sisi Lain Hukum Di Indonesia, Kompas, Jakarta.

Soetardjo Kartohadikusumo. 1984. Desa. Jakarta: Balai Pustaka.

Suhartono. 2002. Politik Lokal, Parlemen Desa Seak Paska Kemerdekaan Sampai Jaman Otonomi. Yogyakarta: Lapera Pustaka Pertama.

\section{Jurnal}

Chenny Engglyn Wungow. 2016. Peran Tokoh Masyarakat Dalam Pembuatan Peraturan Desa (Studi Di Desa Lolombulan Makasili Kecamatan Kumelembuai Kabupaten Minahasa Selatan) lihat https://ejournal.unsrat.ac.id/index.php/jurnaleksekutif/article/viewFile/12 242/11822di unduh pada tanggal 16 Agustus Jam 09.30 Wib 
Darwin Ginting, 2011, Konsepsi Otonomi Daerah Sebagai Alternatif Pilihan Dari Tuntutan Bentuk Negara Federal Di Indonesia, Jurnal Wawasan Hukum, Vol. 25 No. 02 September.

Jossy Putra Arie Wiranda. 2006. "Fungsi Badan Permusyawaratan Desa Dalam Penyelenggaraan Pemerintahan Desa (Studi Kasus Di Desa Pelita Kanaan Kecamatan Malinau Kota Kabupaten Malinau), Ejournal Pemerintahan Integratif, Volume 4, Nomor 2, 2016: 233-244.

Sutoro Eko. 2005. "Masa Lalu, Masa Kini, Masa Depan Otonomi Desa (Pasang Surut Otonomi Daerah,Sketsa Perjalanan 100 Tahun)", Institute For Local Development Dan Yayasan Tifa, Jakarta, hal 444

Taufiqurrahman. 2010. "Konvergensi Paradigma Dalam Perubahan Karakter Pilihan Hukum Di Bidang Kontrak Jual Beli Barang Internasional”, Jurnal Reportorium, Vol 1 No 1

Yuniadi Mayowon, Kemitraan Antara Pemerintah Desa, Bpd, Dan Peran Sekretaris Desa Di kutip : http://ymayowan.lecture.ub.ac.id/2012/01/kemitraan-antara-pemerintahdesa-bpd-dan-peran-sekretaris-desa/ 